\title{
O Crescente uso de Poliuretanas Derivadas do Óleo de Mamona no
} Mercado de Polímeros

por Hugo F. Ramalho

poliuretanos (PU) são polímeros sintetizados a partir de poli-isocianatos e polióis e estão presentes em muitos objetos que são usados diariamente por grande parte da população, como espumas para colchões e estofamentos em geral, tecidos, revestimento para calçados, entre outros. ${ }^{1}$ Nas últimas duas décadas, os polióis utilizados para a produção de PU originados do petróleo vêm gradativamente sendo substituídos por um poliol bastante interessante, presente no óleo de mamona, do qual o Brasil é um dos maiores produtores do mundo. Este óleo aparece como uma fonte renovável para a produção deste polímero, e vem ganhando destaque no mercado de polímeros.

A produção do óleo de mamona foi muito incentivada como forma de desenvolvimento regional, principalmente na região Nordeste. Inicialmente apostou-se no uso deste óleo como fonte para produção
Data de publicação na Web: 15 de fevereiro de 2013 Recebido em 4 de novembro de 2012 Aceito para publicação 10 de fevereiro de 2013

de biodiesel, especialmente durante o Governo do exPresidente Luiz Inácio Lula da Silva. Apesar de todo o incentivo, o seu uso como biocombustível não "vingou" por causa de problemas técnicos provenientes da estrutura química do seu principal componente. $\mathrm{O}$ óleo possui aproximadamente $90 \%$ de ácido ricinoleico, o que faz com que o biodiesel de mamona esteja fora das especificações da ANP, principalmente com relação à viscosidade. Com isso, os investimentos na produção de óleo de mamona para fins energéticos foram drasticamente reduzidos.

demanda por esta matériaprima no mercado. Levando em conta somente o seu uso como poliol, a demanda de óleo de mamona para este fim cresceu de 4.200 ton/ano no ano de 1997 para 27.500 ton/ano em $2006^{2}$ no Brasil.

Apesar de o alto valor do óleo de mamona tornar o valor do polímero de PU três vezes mais caro do que aquele feito com os polióis tradicionalmente usados, sua biodegradabilidade é uma das principais razões para a entrada deste produto no mercado. Por isso já foram atribuídos os termos "biopolímero" e "polímero sustentável" ao PU derivado da mamona.

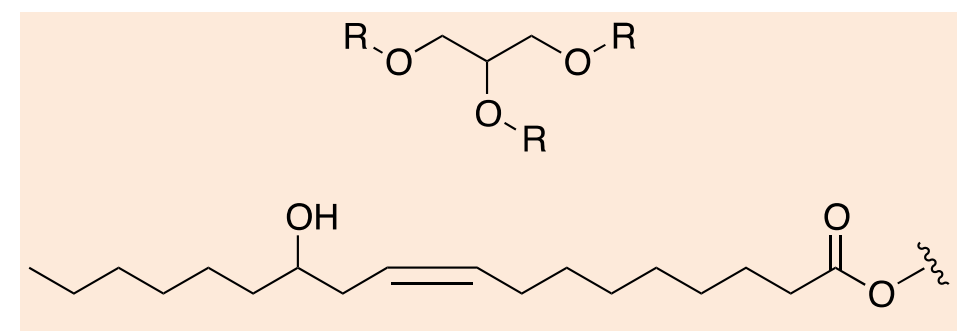

Figura 1. Triacilglicerídeo do ácido ricinoleico

Com o advento das novas aplicações para o óleo de mamona, houve um consequente aumento da três vezes mais caro do que 
aquele feito com os polióis tradicionalmente usados, sua biodegradabilidade é uma das principais razões para a entrada deste produto no mercado. Por isso já foram atribuídos os termos "biopolímero" e "polímero sustentável" ao PU derivado da mamona.

Independentemente das
suas vantagens e desvantagens, o uso do PU derivado do óleo de mamona é uma realidade no Brasil. Diversas empresas como SINERGIA Química e Silaex Química já oferecem serviços como revestimentos de piso, isolamento acústico, produção de espumas e adesivos, aplicação em revestimentos para calçados, entre outros. Um produto interessante que também já é comercializado é a prótese de diversas partes humanas, porque os polímeros feitos a partir do óleo de mamona sofrem pouca ou nenhuma rejeição do organismo, além de serem mais baratos do que os tradicionais.

\section{Agradecimentos}

O autor agradece às diferentes agências que financiam as pesquisas do Grupo de Pesquisas Rede de Estudos em Oleoquímica (CNPq, FINEP, FAPEAL, FAPDF), ao INCT-CATÁLISE e em especial àCAPES (PROCAD 2005, Projeto no 0023051; e PROCAD NF 2009, Projeto no 735/2010) que permitiram a mobilidade de alunos e professores das equipes. $\mathrm{O}$ autor agradece também ao CNPq e CAPES pelas bolsas de pesquisa concedidas aos pesquisadores e alunos de graduação e pós-graduação.

\section{Referências bibliográficas}

1 Beneš,H.; Černá, R.; Ďuračková, A.; Látalová, P. J. Pol. Env. 2012, 20, 175. [CrossRef]

2 Sítio da Associação Brasileira da Indústria Química. Disponível em: <http://abiquim.org.br/poliu retanos/oqueepoli.asp>.

Acessado em: 15 fevereiro 2013.

Universidade de Brasília, Laboratório de Materiais e Combustíveis, Instituto de Química, CP 4478, CEP: 70904-970, Brasília-DF, Brasil.

Mhframalho@unb.br

DOI: 10.5935/1984-6835.20130011 